\title{
"First Contact" and Other Israeli Fictions: Tourism, Globalization, and the Middle East Peace Process
}

\author{
Rebecca L. Stein
}

n the summer of 1994, several days before the signing of the Washington Dec-

laration that would end the official state of war between Israel and Jordan, one of Israel's most popular daily newspapers documented the "first" Israeli visit to Petra, the Nabatean city in southern Jordan. A two-page spread, featured in the front section of Yedi' ot Aharonot and illustrated with photographs, recounted the clandestine voyage of two Israeli travelers who had crossed the border into Jordan illegally with their European passports. "I Got to the Red Rock!" the headline proclaimed. Dramatic, first-person prose recounted the travelers' mounting anticipation as they neared Petra in a Jordanian taxi, their constant fear of discovery, and, at last, the thrill of arrival. "And then it happened. Suddenly, between the crevices of the giant stones, 100 meters from us, [we caught our] first glimpse of the red structures hewn in rock. Tears came to our eyes. . . 'Photograph me,' we said to each other in the same breath" (Lior 1994).

Israeli voyages into the Arab world received extensive coverage in the mainstream Israeli media of the mid-1990s. The figure of the Israeli tourist, and the grammar of a tourist imagination, constituted crucial discursive tools by which popular newspapers represented the so-called Middle East peace process, and its

Earlier versions of this article were presented to audiences at Stanford University, the University of Washington, and Amherst College. Many thanks to Ann Anagnost, Joel Beinin, Yael Ben-Zvi, Robert Blecher, Elliot Colla, Andrew Janiak, Kaylin Goldstein, Jake Kosek, Donald Moore, Andy Parker, Matthew Sparke, and Public Culture's anonymous reviewers for a wealth of insightful readings and suggestions.

Public Culture 14(3): 515-543

Copyright () 2002 by Duke University Press 
effects, to mass reading publics. Stories about tourism were important vehicles of translation. While the intricacies of diplomacy and political economy could be difficult to convey in the popularized vocabularies of the press, stories about leisure travel were not. The figure of the tourist was highly intelligible, even banal in its intelligibility. Tales of the Jewish Israeli leisure traveler, traversing borders into neighboring states heretofore off-limits, were deployed to narrate the effects of regional reconfiguration. Through the image of the traveling tourist body, crossing borders made porous by "peace," the press illustrated Israel's new diplomatic and economic place within the Middle East. Through the highly recognizable figure of the tourist, newspaper readers contended with new maps and new meanings of the Israeli nation-state in an increasingly regionalized and globalized age.

Using the tourist as a lens, this essay examines the ways in which the Middle East peace process, and the shifting relations between Israel and the Arab world, were represented and managed within popular Israeli media of the mid-1990s. ${ }^{1}$ My investigation is framed by the tenure of the Rabin/Peres Labor-led administration (1992-96), the formative years of the Middle East peace process, which began in earnest with the Oslo accords of 1993, as the Israeli state negotiated a political settlement with the Palestinians and neighboring Arab countries. Through the Oslo process, the Labor administration hoped to build a regional economy and common market with Tel Aviv at its center-a political blueprint celebrated euphemistically as "the New Middle East." For the Israeli business community, "peace" held economic promise on a far grander scale; analysts argued that diplomatic and economic agreements with the Palestinians and the Arab world, in accordance with liberalization within the nation-state, would enable Israel's fuller integration into the global economy. For the Labor administration, "peace" was also designed as a security arrangement in which the Palestinian Authority would collaborate in the work of the Israeli occupation to ensure the safety and integrity of the Jewish state.

While the Oslo process failed to alter the regional balance of power, it had a profound effect on the "national order of things" within Israel (Malkki 1995: 70).

1. I use the terms Middle East peace process, Oslo process, and peace process interchangeably to refer to the bilateral, trilateral, and multilateral negotiations conducted during the 1990s between Israel, the Palestinian Authority, and Arab states. My use of the word peace and the phrase New Middle East is not intended to endorse the political ideologies and processes that they denote, but aims to draw attention to the ways this rhetoric circulated in dominant Hebrew discourse. My use of scarequotes aims to place these terms "under erasure" in the Derridean sense. Save my reference to "peace," to which vigilant attention is required, I will henceforth omit scare-quotes. 
As the state and private sector developed stronger diplomatic and economic ties with neighboring Arab states, and as territorial borders became flexible in new ways, cultural and ideological borders began to shift and come to crisis. At issue were a new set of questions and anxieties about Israeli identity in the era of "peace" and the place of a Jewish state within the Middle East. Tourism was at the center of these multiply shifting terrains. As a market, it was both product and progenitor of Israel's integration into new regional and global economies; as a field of both representational and spatial practices, it was a crucial tool by which differently situated Israeli communities explored and contended with the meaning of Israeliness in the peacetime era.

This essay investigates the popular grammar of the peace process era by focusing on representations of tourism in Israel's most widely consumed Hebrewlanguage daily newspapers, Yedi'ot Aharonot and Ma'ariv. ${ }^{2}$ I look at two narratives that were repeatedly deployed during this period. The first is a story of "first contact," in which the Jewish Israeli tourist was cast as discoverer in/of the Arab world. Through a grammar of discovery, which reiterated the stock conventions and gestures of imperial travelogues, tales of discovery in the Arab world functioned to shore up the boundaries of the Israeli nation-state, to preserve the fiction of Israel as a discrete territorial and cultural unit at precisely the moment that borders were being traversed by new kinds of regional and global flows. The second was a less laudatory tale about incoming tourism from the Arab world. While the Jewish Israeli tourist was portrayed as a heroic traveler, freely traversing borders into Arab lands hitherto untouched by an Israeli presence (or so the press suggested), the Arab tourist seeking entry into Israel was the object of considerable anxiety. Through the menacing and often illegible figure of the Arab tourist, the press evoked and managed the threats posed by the permeable borders of the New Middle East and the incoming flows of Arab persons, cultures, and things that "peace" was beginning to deliver.

Citizenship was supremely at stake within these tourism narratives. Indeed, the question "Who is a tourist?"- as enunciated through both legal and popular cultural registers - could often be read as "Who is a citizen?" The relationship between these key terms (tourist/citizen) was highly variable. Stories about Israeli tourists traveling into the Arab world turned on an isomorphic relationship,

2. The newspapers Yedi'ot Aharonot and Ma'ariv, both published in Tel Aviv, had daily circulations of 250,000 and 160,000 respectively during this period. My analysis also includes reference to the Hebrew dailies Ha'aretz and Davar Rishon; the regional and/or urban Hebrew weeklies Kol Ha'ir (Jerusalem) and Kol Hatzafon; and the Jerusalem Post and the Jerusalem Report, Israel's primary English-language publications of this period. 
whereby good tourist looked like good citizen. In stories about Arab tourists in Israel, however, the very authenticity of the tourist depended precisely on his or her difference from the (Israeli) citizen. In the case of the former narrative, good tourists/citizens had very particular profiles; despite the diverse populations of Israelis traveling through the region during this period, this figure was perpetually cast as Ashkenazi, a Jew of European descent ${ }^{3}$ - a move consistent with the Ashkenazi bias of the popular Hebrew press, and more pointedly, with the hegemonic terms of Israeliness on which the state had been founded. ${ }^{4}$ In turn, stories about incoming Arab tourists (or the threat thereof) worked to shore up the borders of the nation-state, preserving its Jewishness in the face of shifting demographics and regional geopolitics that threatened Israel with Arabization. Yet the popular press was an ambivalent text; in the slippages and anxieties that attended stories about tourism, newspapers exposed precisely the instabilities of dominant Israeli ideology in the era of "peace" and the possibilities for its remaking.

In the broadest terms, I am suggesting that "the tourist" be read as a surrogate - a figure that stood in for something else. This is not to discount the material importance of tourism in the Oslo peace process and its emerging markets but to suggest that the significance of tourism in the popular press exceeded the register of political economy, even as it was articulated through it. In Israeli newspapers, stories about tourism were simultaneously stories about the nation-state, about the meaning and boundaries of Israeli identity, citizenship, and culture during the peacetime era. Their function was two-fold: they worked to regulate the flows of bodies, culture, and things (both real and imagined) across the border, in

3. Ashkenazi Jews of Russian, Polish, German, and central European descent have historically made up Israel's elite class and have dominated Israel's cultural, economic, and political institutions since the early years of state formation. Although largely excluded from elite institutions, the Mizrahi Jewish population (including Jews from North Africa, the Middle East, and the Levant) constituted the majority of Israel's Jews in the decades following their mass migration to Israel in the 1950s. With the arrival of some 700,000 Jews from the former Soviet Union in the first half of the 1990s, this majority status was lost. Note that despite their ethnonational origins, immigrants from the former Soviet Union have not been able to claim Ashkenazi privilege, due to their class background, lack of schooling in Zionist culture, and the numerous rabbinical challenges to their Jewishness. Jews who migrated to Israel from England, South Africa, and the United States have historically exercised Ashkenazi privilege and yet have been largely excluded from dominant positions within Israel's elite institutions. See Chetrit 2000 and Courbage 1999 for analyses of changing ethnoracial demographics and power relations in Israel during the 1990s.

4. The readership of Yedi'ot Aharonot and Ma'ariv has long been relatively diverse, including Jews of European descent (Ashkenazim), Jews who immigrated to Israel from Arabic speaking countries (Mizrahim), and Palestinian Arabs with Israeli citizenship. Despite this broad consumer base, both papers have historically observed the terms of dominant Israeli ideology by focusing on Ashkenazi Israel—its cultures, political circuits, and institutions (Avraham 1993). 
and out of the Israeli nation-state and to performatively reproduce a set of knowledges about the nation-state and its subjects during this period of both regional and national flux. These stories demarcated the difference between home and away, consolidating the ideological boundaries of the nation-state, at precisely the moment that physical borders were becoming porous in new ways. The highly legible and recognizable figure of the leisure traveler illustrated the reorganization of political alliances, economies, and circuits of labor within the "New Middle East" of the peacetime era.

In part, this essay emerges out of, and seeks to complicate, the discussion and deployment of tropes of travel by cultural theorists of the last two decades. In the early nineties, images of travel and the traveler were used to illustrate postmodern hybridity and to shatter the presumed isomorphism of community, culture, and place by theorizing and historicizing subjects at points of transience and flux (Clifford 1989, 1992; hooks 1992). More recently, traveling subjects have been marshaled as illustrations of globalization and/or transnationalism, offered in the form of a laundry list ("tourists, immigrants, refugees, exiles, guest workers") (Appadurai 1996: 33). As Caren Kaplan (1996) has suggested, the traveling subject as trope of global flow tends to obscure the historical conditions of travel for differently situated communities and the discrepant relations of power that attend them. In other words, laundry lists risk an equivalence effect, whereby differences among disparate histories and experiences of travel are smoothed over or ignored. Rather than merely dismiss such tropes for their leveling effects, this paper explores the meanings and effects of their deployment in a particular historical context, in an effort to take these tropes seriously as both effects and catalysts of larger political, economic, and social processes. By conjoining discourse analysis with political economy, I seek to complicate the prevailing scholarship on the Middle East peace process with its singular attention to the macroeconomic effects and diplomatic histories of peace making by considering some of the quotidian discursive economies in/by which the peace process was represented and managed. My reading also seeks to illustrate the uneven regional geographies of mobility, prosperity, and power that the Oslo process has generated in the last decade, even as it suggests the relative fragility of Israeli hegemony in the global era.

This study of Israeli tourism discourses must be read in the context of multiple histories of travel and movement that far exceed the scope of this essay. They include the Zionist migration to Palestine beginning in the late nineteenth century; the flight and expulsion of some 700,000 Palestinians in the course of the 1948 war; the Mizrahi emigration of the 1950s and subsequent decades of state- 
sponsored peripheralization; the itineraries of Israeli soldiers and settlers in Arab places, in the context of occupation and/or military incursion (in Lebanon, Sinai, the West Bank and Gaza Strip); ${ }^{5}$ and the ways that tourism practices and discourses have been enlisted in the material and symbolic service of the Israeli occupation. My study of leisure travel articulates with, and because of, these legacies.

\section{The Oslo Peace Process and Its Economies}

While negotiations between Israel and neighboring Arab states have been openly pursued since the 1967 war, the Oslo accords of 1993 were celebrated in the Israeli and international media as the first significant breakthrough in Israeli-Palestinian negotiations (Bar-Siman-Tov 1994; Quandt 1993). Yet, as many Palestinian critics have argued, the accords did little to alter the geopolitical balance of power in the region: signed by Yasser Arafat in an attempt to secure his regime in a time of political and economic crisis, the Oslo accords reconfigured the terms of Israeli power in the West Bank and Gaza Strip through a new partnership with the Palestinian Authority (Murphy 1995; Rabbani 1996) but did not achieve a significant redistribution of that power. ${ }^{6}$ The accords stipulated mutual recognition between Israel and the Palestinian Liberation Organization (PLO) and the beginning of Israeli withdrawal from Palestinian territories occupied in 1967. They offered the Israeli government the economic and political gains of an internationally recognized rapprochement with the Palestinian people but necessitated little territorial compromise, leaving Israel in control of land, security, the economy, and all matters pertaining to the Jewish settlements within the West Bank and Gaza Strip. Despite the symbolic trappings of statehood (e.g., Palestinian postage

5. Following the 1967 war and Israel's occupation of Arab and Palestinian lands, Jews flocked to the East Jerusalem Old City for "authentic" Arab food, to the Sinai coast for natural beauty and Bedouin culture (Lavie 1990, 1988), and to the markets and restaurants of Bethlehem and Ramallah for inexpensive shopping on Friday afternoons. After the Camp David accords of 1978, hundreds of thousands of Israeli Jews visited Cairo and Alexandria. The first Palestinian uprising put a temporary end to West Bank itineraries. After the Oslo accords, Jewish settlements in the West Bank and Gaza began to develop tourist facilities, but few Israeli Jews returned as tourists to Palestinian towns and cities in the West Bank and Gaza Strip (Stein 1995).

6. By the early 1990s, political and economic conditions in the West Bank and the Gaza Strip were deteriorating: the PLO was crippled by the loss of revenue and military support from the former USSR and from Gulf patrons following the Gulf War; the intifada had fallen out of favor with the Western media, partially due to Arafat's alliance with Sadam Hussein; and, as poverty grew in the West Bank and Gaza Strip alongside dissatisfaction with Arafat's regime, the Islamic movement Hamas was becoming an increasingly popular alternative to the PLO (Aruri 1995). 
stamps, passports, and uniformed immigration officers), the Palestinian governing entity and its territorial borders remained "legally subordinate to the authority of the [Israeli] military government" (Aruri 1995: 223, 213).

The Oslo accords had profound effects on the Israeli economy (Shafir and Peled 2000). "Peace" with the Palestinians paved the way for Jordan and Israel to sign the Washington Declaration in July 1994, thereby ending the official state of war between the two countries; in turn, Arab nations ended their forty-year boycott of Israeli goods and commercial partnerships and their ban on third-party dealing with Israel.7 By many accounts, the "Arab boycott" had long been a public fiction, belied by a history of covert trade between Israel and the Arab states in everything from arms to agriculture (Shahak 1994). Yet the official dismantling of the boycott regime had serious effects (Seliktar 1998). Without the boycott as obstacle, Israeli companies began to look toward neighboring nations as potential markets, suppliers of cheap labor, subcontractors, business partners, and targets of investment. Israel increased its trade with North African countries (particularly Morocco and Tunisia) and opened trade representation offices in Qatar and Oman. The Israeli private sector pursued regional ventures with Jordan, Egypt, and the Palestinians in the areas of tourism, transportation, water, and the environment. Israeli textile firms began to transfer plants over Israel's eastern and southern borders in search of inexpensive labor (Seliktar 1998; Shafir and Peled 2000). At issue was less an emerging "regional economy," as proclaimed by the Israeli state and private sector, than a regionalized Israeli economy that was beginning to mine the Arab world for new markets, sites of production, and labor pools - thereby fortifying the pre-Oslo balance of power. ${ }^{8}$

The dismantling of the secondary and tertiary tiers of the Arab boycott banning third-party dealings with the Jewish state produced major economic gains for Israel. Prior to the 1990s, Israel had been largely ignored by European and Asian multinationals. In the first two years after the Oslo accords, Israel's national economy grew significantly due to a surge in foreign investment and consumer confidence. Total foreign investment in Israel increased by $\$ 4.7$ billion to $\$ 19.6$ billion, and several U.S. high-tech corporations (including Intel, IBM, and

7. The primary "Arab boycott" against Israeli products was instituted in the late 1940s. The secondary boycott, established in 1952, blacklisted firms that traded with Israel, followed by a tertiary boycott imposed on firms that traded with Israel. On 1 October 1994, the Gulf Cooperation Councilincluding Saudi Arabia, Bahrain, Kuwait, Oman, Qatar, and the United Arab Emirates — ended its blacklist of Israeli goods and companies with Israeli ties (Seliktar 1998).

8. As of 1998, Israel's per capita GNP was six to ten times higher than that of neighboring states (Mundlak 1998: 202). 
Microsoft) announced major new investments in the country - investments made possible in part by a large, skilled workforce of Russian immigrants trained in science and technology (Beinin 1998). In turn, Israeli companies began to globalize, working through regional channels. The Israeli textile industry was a selfproclaimed "pioneer" in this regard; in the 1990s, raw cotton was being purchased in Egypt, sent to Turkey for spinning and weaving, to Israel for designing, to Jordan for sewing and packaging, and finally shipped for sale in the United States. In tandem, Israeli capital was flowing to Asia as never before; following the end of the boycott, Israeli companies began exploring markets in Malaysia, India, Vietnam, and Indonesia. Government ministers spoke of Israel as the future "Singapore of the region"- a hub between Asia and Europe. 9 Through the channel of the regional, "peace" was globalizing the Israeli economy. Indeed, the process was dialectical; the regional processes generated by Oslo enabled global ones, even as the globalization of the Israeli economy had regional effects.

In accordance with the dual axes of commerce and "security" on which the Oslo process turned, globalization depended on Israel's violent containment of the occupied Palestinian territories. In March 1993, the Labor administration began to pursue a policy of military closure by which the West Bank and Gaza Strip were effectively sealed from each other, the Jerusalem area, and Israel proper in an effort to protect Jewish citizens from "Arab terror." The number of Palestinians granted permits for work inside Israel fell dramatically - from approximately 120,000 daily in 1992 to 36,000 in 1996 . To replace the Palestinian bluecollar workforce, the government began importing workers from nations where non-Arab labor could be contracted at minimal costs (Romania, Thailand, Nigeria, Ghana, the Philippines). Due to a history of Palestinian dependence on the Israeli economy, the policy of closure produced high rates of unemployment (escalating from 11 percent in 1993 to 28 percent in 1996), vastly reduced levels of Palestinian trade and production, and heightened poverty (Ben Efrat 1993; Farsakh 2000). In keeping with the terms of the Oslo accords, Israel maintained control over the perimeters of Palestinian areas and prevented Palestinian access to Israeli markets while ensuring Israeli access to Palestinian ones.

The mid-1990s was also a period of tremendous social and political change within Israel—change enabled by shifts on regional and global scales. Israeli Jews of North African, Asian, and Middle Eastern descent (Mizrahim) were demanding

9. Many Israeli economists and market analysts were more cautious in predicting Israel's place within an emerging regional economy, citing "xenophobic restrictions on foreign trade and investment" and popular fears of neocolonial domination within the Arab world, in addition to the gross disparities between national economies (Seliktar 1998; Zilberfarb 1994). 
and gaining new kinds of political visibility and electoral power within Israel. Although they had long constituted the Jewish majority within the state, at least until the large-scale Russian immigration of the 1990s, they had historically occupied the lowest rungs of Israeli Jewish society - victims of state-sponsored peripheralization, underdevelopment, and racism. During the 1990s, as Israel pursued "peace" with its Arab neighbors, Mizrahi voters began to mobilize in unprecedented ways. As a result, Israel's only Mizrahi-identified party, SHAS (Shomrei Torah Sephardim [Sephardic Torah guardians]), greatly increased its parliamentary numbers and power during the national elections of 1996 and 1999, with a strident critique of Ashkenazi hegemony (Chetrit 2000; Courbage 1999). In tandem, Palestinian citizens of Israel were increasingly demanding their civil rights as citizens of the state and reaching new audiences in the Parliament and popular media alike. For the first time, toward the end of the Labor tenure, a Palestinian Israeli politician announced plans to run for prime minister in the 2000 race.

These shifts in Israeli political culture were attended by demographic changes within the nation-state that increasingly threatened (in the words of right-wing analysts) the Jewish character of the state. Israel's Christian communities grew markedly during this decade, as a result of the mass immigration to Israel of nonJews from the former Soviet Union (the spouses of Jewish immigrants) (Courbage 1999: 28). ${ }^{10}$ At the same time, Israel's population of blue-collar foreign workers was growing and beginning to settle in Israeli towns and cities; by 1998, they made up one-sixth of the population of metropolitan Tel Aviv. Perhaps of greatest consequence, population analysts warned, was the precipitous rise in Arab birthrates - both among the Palestinian population living within the borders of Israel and the Arab population within the region as a whole-and the coextensive decline in Jewish fertility. In the mid-1990s, some demographers anticipated an Arab majority within the area of Israel/Palestine by the early decades of the twenty-first century (Courbage 1999: 30). Such statistics seemed to foretell the demise of the Jewish state. As Israel moved toward greater economic and political integration within the Arab Middle East, the ability of the dominant culture to remain both Jewish and European was the subject of considerable anxiety.

10. Demographer Youssef Courbage (1999: 28) explains: "With the massive arrival of Jews from the former Soviet Union beginning in 1991, the Law of Return was de facto extended to include the non-Jewish spouses of Jewish immigrants. As a result, the proportion of Jews among the immigrants fell from about 97 percent in 1990 to 75 percent in 1997.' He notes that Israel's Christian community grew from 107,000 persons in 1990 to 183,000 in 1996 — a tenfold increase (Courbage 1999: 28). 
The Oslo peace process also had a profound effect on the tourism sector in both Israel and the Middle East as a whole. ${ }^{11}$ Indeed, it was in the field of tourism that "peace" generated some of the most substantial regional cooperation and seemed to hold its greatest financial promise - at least in the first few years after the Oslo accords. In fall 1995, Israel joined Turkey and Egypt in establishing the Eastern Mediterranean Tourist Association to coordinate joint marketing of regional itineraries. Simultaneously, the Israeli government announced plans for a series of tourism projects in cooperation with Jordan, including a Dead Sea park spanning the border, joint airport facilities in Aqaba and Eilat, and a "Peace Road" connecting Haifa and Irbid (Government of Israel 1996). In 1995, as the Israeli ministry of tourism hailed "the year of peace tourism," the number of visitors to the Jewish state peaked at a record 2.2 million, generating $\$ 3.1$ billion (Sugarman 1996). With tourism revenues representing over 30 percent of Israel's income from service exports ( $\$ 2.5$ billion), the development of regional tourism promised growth to an already crucial Israeli market (Ministry of Finance 1994). Optimists anticipated a 250 percent rise in revenue as a result of regional marketing, air links between Israel and Asia, newly opened and eased border crossings, and the growth in consumer confidence generated by political stability (Ben Ari 1996; Sugarman 1994).

The Oslo accords also substantially affected the itineraries of Israeli travelers, as diplomatic and economic agreements between Israel and its neighbors made the Muslim Middle East both newly available and attractive to tourists. Jordan was the most popular, and the most possible, new Israeli destination. In the first six months following the Washington Declaration (1994), which ended the formal state of war between Israel and Jordan, some 60,000 Israelis crossed the eastern border for weekend visits to sites heretofore off-limits to Israeli passport holders (Blackburn 1995); between 1995 and 1997, over 100,000 Israelis had paid a visit to the Hashemite Kingdom. ${ }^{12}$ Israeli tourism to Morocco also increased during this period, following the establishment of low-level diplomatic relations with Rabat in 1994. Some 40,000 Israelis, many of Moroccan descent, visited in

11. The Jordanian private sector was equally optimistic about the effects of "peace" and began massive state-sponsored development of the national tourist infrastructure to accommodate the anticipated boom. Yet tourist numbers and revenues decreased rapidly in the late 1990s despite initial growth - fueling popular opposition to "peace" and to normalized relations with Israel. For analysis of Jordan's 1990s tourism economy, see Clawson 1994 and Hazbun 2002.

12. Most Israeli tourists visiting Jordan went to Petra only and many just for the day (Hazbun 2002). 
1995, a dramatic increase from the 2,000 who had come annually (and illegally) since the 1980s (Levy 1997; Sedan 1999). Growing numbers of Israelis also traveled to Egypt and the Sinai Peninsula during the post-Oslo period-this despite over a decade of "peace" with Egypt. Some 200,000 visited in 1994, in a 70 percent increase from the previous year (Hiel 1995).

No less monumental was the shifting imagination of Israeli armchair travelers, sites in the Arab world that remained offlimits to Israeli passport holders were becoming available as objects of tourist fantasy. As talks between Israel and Syria progressed in spring 1995, the Hebrew press began to prepare its readers for their impending trips to Damascus, Beirut, and Tunis. In tandem, Israeli tourist agencies began to prepare their clients for travel across a Middle East uninterrupted by borders or political conflict (fig. 1). Prior to "peace," dominant Israeli discourse had conceptualized the distance between Israel and its Arab neighbors largely in terms of military threat. In the mid-1990s, this geography began to change. The New Middle East was now being offered to Israeli consumer-citizens as a singular geography — not of conflict but of leisure.

The Oslo peace process also stimulated geographies of leisure within the nation-state, as "peace" sanctioned new forms of Ashkenazi curiosity in Palestinian Israeli culture. Israeli Jews had long conceptualized the distances between Jewish towns and Palestinian villages (as between Israel and the Arab world) as indices of enmity, real and imagined. In the mid-1990s, they began to reconceptualize these proximities, traveling into Palestinian villages and towns for weekend leisure, returning to places they had visited in the uniforms of the Israeli army or deliberately skirted for fear of politically motivated violence. Palestinian and Jewish entrepreneurs took advantage of the new curiosity and developed a market in ethnic tourism (trafficking in foods, folklore, cultural practices, and historical narratives), and it soon gained the symbolic and fiscal support of the ministry of tourism (Stein 1998). Only certain forms of Palestinian culture were sanctioned by the state and deemed attractive to the Ashkenazi tourist-consumers that frequented this market: those that bore the recognizable marks of "authenticity" (the rural untouched by modernity) and the cultural diacritics of a desituated "Arabness," stripped of the threatening traces of Palestinian ethnonationalism (Stein 1998).

Yet not all proximities were cause for celebration. The possibility of Amman, 
Damascus, and Beirut as potential Israeli tourist sites was predicated on the simultaneous absence of the cities and towns that "peace" could less easily abide. Even as Jewish tourists began crossing the border into Jordan or traveling north to the Palestinian Galilee for weekend leisure, they continued to avoid the cities and towns of the West Bank and Gaza Strip, as they had since the first intifada (198791). More than touristic appeal or "safety" was at issue here. The new geography of Jewish Israeli leisure obeyed the political and cultural logic of the New Middle East with its provisional links between Israel and neighboring states and its highly regulated divides between Israel and the occupied Palestinian territories.

\section{Tales of Discovery}

How did the mainstream Israeli press contend with the Oslo peace process? How did it make sense of Israel's changing relationship to the Arab world and its new participation within regional and global economies? The figure of the Israeli tourist, traversing Arab lands, was a popular means of representing these cultural and political-economic processes to mass Israeli readerships. The narrative of "first contact," in which the Jewish tourist was celebrated as discoverer in/of an Arab world previously unavailable to Israeli passport holders, was particularly prominent in the Hebrew press during this period. Through stories of discovery, which relied on an imagined history of noncontact between Israel and its Arab neighbors, the Oslo peace process could be lauded as heroic for its rupturing effects. Jordan was the foremost object of Israeli discovery - both because it was the first Arab state to open its borders to Israeli travelers during this decade and because of its alluring proximity. ${ }^{13}$

To begin, I return to the 1994 newspaper account of the "first" Israeli tourists in Petra with which this essay began. The Israeli arrival in Petra could only be imagined in heroic terms; Petra was a place long immortalized in Israeli myth, the subject of collective longing, popular song, and children's stories. Beginning in the 1950s, clandestine travel to this Nabatean city had been a virtual rite of passage for young Israeli men who risked their lives in enemy Jordanian territory

13. The story of "first contact" was also deployed by the Hebrew press to describe Israeli tourism to Egypt in the wake of the Camp David accords of 1978, ending the formal state of war between Israel and Egypt. Yet this narrative was mitigated by the breadth of popular and academic (notably archaeological) Israeli knowledge about ancient Egypt. Thus, unlike the story of Israeli tourism to Jordan in the wake of the Washington Declaration, the popular narrative of Israeli "first" visits to Egypt did not presume discovery of the previously unknown - but rather its rediscovery in the "modern" age. 

desire for Petra was firmly embedded in the national Israeli imagination. In the press, the Israeli tourist was installed to consummate that desire:

Now we are here, descending on foot on the donkey path, and my heart is beating wildly. When no one is around, we speak in Hebrew - certainly the first conversation that has been had here, in this language, for many years. Suddenly, standing out from two sides of the narrow path, the giant red rocks rise proudly, casting a menacing glance on the small figures that move between them. ... And then it happened. Suddenly, between the crevices of the giant stones, 100 meters from us, [we caught our] first glimpse of the red structures hewn in rock. Tears came to our eyes. . . . "Photograph me," we said to each other in the same breath. (Lior 1994)

The thrill of arrival depended on a companion narrative of secrecy and disguise. Our visitors speak a careful Hebrew, only out of earshot, in a place where Israeli Jews had long feared to tread. The text is rife with the standard tropes of discovery, drawn from the archive of colonial travel: the ardor of a clandestine voyage, the mounting anticipation as the site is neared, the victorious testimonial upon arrival, the virtual invisibility of indigenous bodies/subjects that might sully the landscape and mitigate the rhetoric of "first contact" (Greenblatt 1991; Pratt 1992). The act of "discovery" is explicitly thematized and its excitement preserved through recourse to a perpetual present tense: "Today, at this moment, [Petra] is being discovered by two Israeli journalists with the excitement of children. I pinch myself to confirm it" (Lior 1994).

The narrative of discovery was substantiated by a photograph (fig. 2). Like the televised images of this scene of "first contact," shot by the same journalists with a handheld camera and aired that evening on the Hebrew news, the quality of the photograph is poor. The image is grainy and overexposed, with the Israeli journalist squarely at its center, posing before Petra's mythic red rocks with a compact camera worn like a medal of honor. In its composition and amateurism, the photograph is recognizable as "the tourist snapshot." The thrill and drama of the clandestine arrival depends on this quotidian portrait — on the story of common travelers crossing state lines. Through the very familiarity of its tropes, through its evocation of the conventional signifiers of leisure travel, the photograph con-

14. Petra was first introduced to Western travelers in the nineteenth century through John Lewis Burckhardt's Travels in Arabia (1829). A century of travelers followed Burckhardt's lead, including orientalist scholars, who traveled in disguise as Muslim pilgrims, and Christian pilgrims, who traversed the Holy Land in search of biblical geography. 

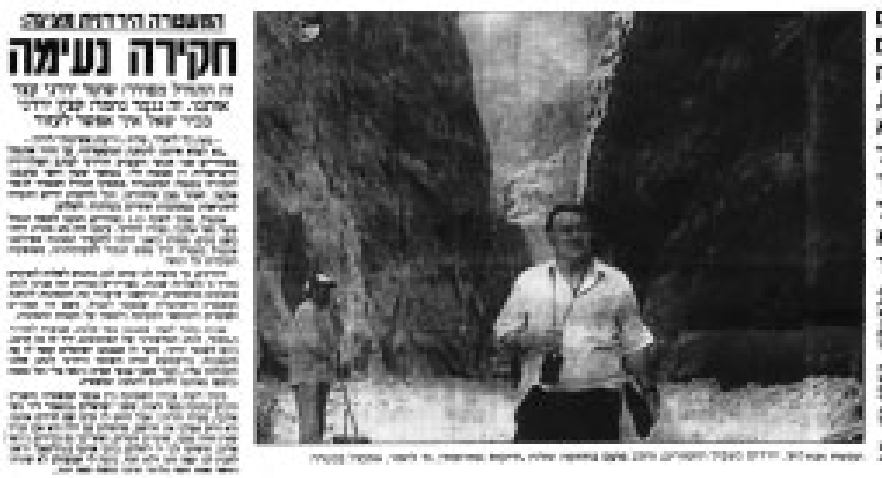

roton vo 1 as , cums troe warn an mon

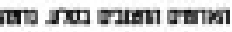
ine ral mas nome ?

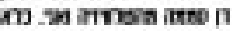

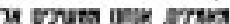

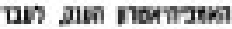

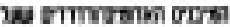

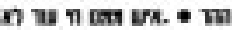

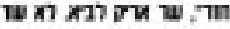

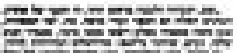

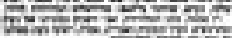

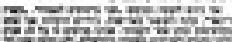
6. orizezson

Figure 2

"I Got to the Red Rock"

stitutes the proof of presence. The photograph assures us not simply that "they were there" but that "being there" happened in familiar ways. As the companion narrative suggests ("photograph me") the discovery must be documented and witnessed to be true. ${ }^{15}$ Indeed, the story of first contact depends on a double act of verification - on site, with handheld camera, and by readers of the press, through consumption and recognition of the image.

Discovery was also an act of subject formation. In the consummate moment of arrival, and the rituals of documentation that attend it ("photograph $m e$ "), the discover-subject is made visible; that is, the "I" is reconstituted at the moment of first contact ("I Got to the Red Rock"). For newspaper readers, the very recognizability of the discoverer qua tourist functions as a moment of interpellation, albeit one that can be refused. Through consumption and recognition of the photograph and the standard tropes of tourism that attend the narrative, the reader is hailed as tourist/discoverer. Given that a collective Israeli longing for Petra began

15. Mary Pratt (1992: 240) describes a similar phenomenon in Victorian discovery rhetoric and the role of material evidence in making it "real": "The "discovery' itself, even within the ideology of discovery, has no existence of its own. It only gets 'made' for real after the traveler (or other survivor) returns home, and brings it into being through texts: a name on a map, a report to the Royal Geographical Society, the Foreign Office." 
just after state formation, discovery was considerably belated. Yet, however belated, the narrative's present tense rendered discovery both immediate and always already new ("Today, at this moment, Petra is being discovered . .."). Through consumption of texts like this one, readers of the Hebrew press discovered Jordan and were hailed as Israeli discovers over and over again.

Similar stories of first contact proliferated in the pages of the Israeli press during the period. Indeed, the scene of discovery in Jordan would be restaged less than one month later. On 12 August 1994, three days after the border legally opened to third-party passport holders, images of "the first Israeli tourists to return from Jordan" appeared again on the front page of a popular Hebrew daily. And this scene would recur in November, when the border was officially opened to all Israeli travelers, regardless of passport (prior to this date, representatives from the tourism ministry explained, Israeli tourists had crossed the border in violation of international agreements). In the months that followed, the press announced the first private Israeli vehicles to cross into Jordan, the first flights between Tel Aviv and Amman, and the first direct bus service to the Jordanian capital (Levinshtein 1996). Some "firsts" were more quotidian, like tales of Hebrew spoken by tourists in select Jordanian towns "for the very first time." Some were cautionary, as in "the first time since ['peace'] that a Jordanian newspaper printed a racist article against Israeli tourists" (Abu-Tuma 1995). As the peace process grew in scope, stories of first contact were told of other placesannouncing the arrival of Israelis to Yemen and Tunisia. And this narrative was mobilized to anticipate future routes to places that remained inaccessible to Israeli civilians - Syria, Lebanon, and the Gulf States. The power and credence of this narrative relied on its sheer proliferation. And yet in proliferation, the narrative of "newness" was perpetually undone. Each successive "first" required the forgetting of its antecedent.

The idiom of the tourist guide was critical in producing the story of first times and "introducing" the geography of the Middle East to Jewish Israeli readers. These narratives worked to secure the ideology of discovery and to realign the threatening political geography of the Arab world as an inviting cartography of leisure. As Israel pursued negotiations with Syria in the winter of 1994, newspapers acquainted their reading publics with streets and sites of Damascus (A. Lavi 1995). One offered tips on shopping, museum going, and proper ways of bargaining (Shalit 1994). Another offered its readers “Thirty Things You Didn't Know about Syria," with lists of useful facts and attractive vistas (M. Lavi 1995). Regional itineraries were shifting dramatically for the Israeli tourist. With the Arab world becoming available in new ways, the merits of particular Arab cities 
could now be measured relationally: "[The Damascus market] is all very authentic. There's no system of double prices - one for tourists, one for locals-like in Jordan. And they don't ask for baksheesh like in Egypt" (Shalit 1994). North Africa, Yemen, and the Gulf States were also being inscribed onto an Israeli touristic cartography in new ways, following diplomatic and economic advances in the Oslo peace process. On the occasion of Shimon Peres's first visit to Qatar, the press introduced its readership to "The Qatari: Our New Friend in the East" through an imagined encounter with Israelis "in the world of tourism" (Kaspit 1996). In the spring of 1996, newspapers announced "Yemen: Starting to Open to the World" and featured Tunisia as an "Oasis in the Sahara" (Teiman 1996; Tunisia 1996). When snapshots of first contact were unavailable, they had to be anticipated; the streets of Tunis were depicted with a photograph of an empty marketplace, above the caption: "Soon to be a center of Israeli tourism" (Shehori 1996).

The "discovery" of the Arab world required a companion narrative on geography. To dramatize the heroism of first contact, the proximity between Israel and its Arab neighbors was cast in the idiom of astonishment. The press deployed a narrative of the "surprisingly near"- that is, of a geography of contiguity that "peace" had only now made visible and available. Newspapers assured readers that the Arab world was much nearer than expected and articulated the allure of neighboring states through the wonder of their proximity. Headlines announced: "Closer Than You Think!" and articles reminded readers that "it's closer than Turkey ... or even Egypt" (Cohen 1994; Schrag and Rodan 1994). The same idiom was employed to entice readers with future itineraries in Syria, stressing Damascus's negligible distance from Israeli urban centers ("An Hour and a Half from Tiberias" [Iss 1995]). Whether articulated in temporal or spatial terms, "proximity" was represented as an effect of regional realignment and its anticipated future. "Peace" was creating "new conditions of neighborliness," changing the way in which Israeli national geography could be told and understood, making the distance and difference between Israel and its Arab neighbors thinkable in new ways (Appadurai 1996: 29). Distances and differences that were once legible only through the coordinates of enmity were now possible to remap through the idiom of leisure travel. Yet distance had no absolute value; Israel's ability to contain Palestinian proximity during this period is what made the celebration of regional proximity possible. 
Diasporic Itineraries

On what did first contact depend? What was at stake in its perpetual reiteration? The story of Israeli newness in the Arab world depended on a set of constitutive exclusions and historical revisions that worked to stabilize the New Middle East, to make the regional geography of contiguity and proximity safe for dominant Jewish culture. Tales of discovery consolidated Israel's difference from the Arab world at precisely the moment that flows of labor, commerce, and capital between Israel and its neighbors seemed to make borders porous in ways that threatened the integrity of the Israeli nation-state. The myth of first contact stabilized the border as both geographic and cultural divide.

Of course, first contact was a fiction - one that relied on an imagined history of noncontact that "peace" effectively ruptured; one that operated through the elision of prior histories of contact between Israel and the Arab world. Although these Israeli tales of discovery borrowed from the archive of colonial travel, the nature of their elisions differed in important ways. Critical to the colonial travelogue and its narrative of discovery, as Mary Pratt (1992) suggests, is the distortion and forgetting of local knowledges and histories of a place - a discursive practice that enables the place to be "found" by the Western traveler. In this act of revision, non-European knowledges and histories of/on the land were disavowed through tales of premodern waste and primitivism. The Israeli case was different. At issue, in the Israeli press, was less a revision of "local" knowledges/histories than a willful forgetting of Israeli ones - that is, of prior Jewish Israeli histories in Arab world. Of particular consequence were those pertaining to the Israeli army and to the violent Israeli itineraries born of war, occupation, and incursion. The forgetting of these histories enabled the "discovery" of Beirut as Israeli tourist destination - this despite the 1982 invasion of the capital city, when many Israeli soldiers passed through its historic districts. A similar process of forgetting enabled the emergence of Tunis as "first-time" leisure destination - this despite a history of Israeli efforts to monitor (and assassinate) PLO leadership in this city. The story of "the first time" did the work of historical revision at a moment when national economic interests were supremely at stake. To forget these histories of aggression in the Arab world was to enable new modalities of both collaboration and exploitation in the emerging markets of the New Middle East.

The fiction of first contact also depended on a set of elisions and revisions pertaining to the Israeli tourist population itself. To sustain the myth of discovery, contact between tourist and host was represented as an interface across the lines of difference, and the tourist carried the onus of that difference. In the pages of 
the mainstream Hebrew press, Israelis visiting the Arab world were represented not merely as Jews but as Jews of European descent (Ashkenazim). The tourist's European identity was illustrated through accounts of his or her confusion in Arab places. Numerous articles described the tourist's failure to comprehend Arabic in the midst of the Arab metropolis and celebrated (in the case of Jordan) the ability of hotel and restaurant workers to converse in Hebrew (Cohen 1994). Newspaper accounts frequently described an Israeli tourist populace unable to comprehend the quotidian landscape of the Arab world; the press did the work of decoding this foreign landscape for the Jewish reader qua traveler - translating unfamiliar Arab places and cultural practices into a legible "Israeli" lexicon.

In truth, there were many kinds of Israelis traveling through the Middle East at this moment, with many different itineraries. Despite the press's portrait of the Ashkenazi peacetime traveler, there were many Mizrahi Israelis touring the region during this period, and many lacked the linguistic and cultural incompetence that the press presumed. In the 1980s, and increasingly after the Oslo accords, Jews of Moroccan descent began touring Morocco in unprecedented numbers - a voyage made possible by low-level diplomatic agreements with Israel in 1994 and a Moroccan government eager for revenue from an incoming Jewish market (Levy 1997). Moreover, during this period Mizrahi travelers numbered heavily among the Israeli tourists visiting Turkey (attractively situated in the interstices of Europe and the Middle East). Yet the press's story of first contact, and its presumption of the culturo-linguistic newness of the Middle East, made no conceptual space for these travelers and their itineraries. The same was true of articles that anticipated and invited future travel to Arab places not yet available to Israeli tourists; "Thirty Things You Didn't Know about Syria," the 1995 exposé of Damascus cast as proto-tourist guide, was not addressed to Arab Jewish travelers with prior knowledge of Syria's cultural and political landscapes. The allure of travel in the region relied on a narrative of sights heretofore unseen. Mizrahi travel could not be mobilized to tell a heroic story of discovery, or a tale of "peace" as rupturing event, and thus was not featured in the popular media.

Nor were all Israeli travelers Jewish. Indeed, notwithstanding the presumptions of the press, the vast majority of Israelis traveling to Jordan in the mid1990s were Palestinian citizens of the state (Shapiro 1995a; Ya' ari 1995). As with Mizrahi travelers, their presence among the Israeli tourist masses was invisible within a discovery narrative dependent on an orientalist binary (Europe meets the Arab world). These traveling subjects could not represent the nation-state in the pages of its newspapers; although citizens of the state, they continued to be actively excluded from the national collective ("the people of Israel") as they had 
been since Israel's founding. The invisibility of these travelers was heightened by the relative visibility granted Palestinians from the occupied territories, whose voyages to Jordan, while never celebrated as "discoveries," were sometimes chronicled in the back pages of the Hebrew press. Consider the following excerpt, from an article entitled "They Were There," which offered tips on Jordan to the prospective Jewish Israeli tourist, amassed from West Bank informants:

Naseer Adin Nashashibi ... recommends a visit to the Jerash festival. . . . He discourages hitchhiking. ... Sako, an employee in a camera store who requested to remain anonymous, often travels to visit his family. He recommends the Jabri chain of restaurants, especially the one with Americanstyle [food]. . . . Daoud Maoli, a cook at the Munateen restaurant, recommends a visit to the King's castle. (Cohen 1994)

Here, the idiom of the tourist guide obscures the history of Palestinian diaspora and its migratory routes between Israel, the occupied territories, and neighboring Arab countries. The story of a family visit is overshadowed by (in standard tourist register) recommendations for restaurants and entertainment venues. Local knowledge of the place and appropriate behavioral norms is implicitly ascribed to a history of leisure, rather than to the legacy of dispossession that necessitated the journey between Jordan and the West Bank - the itinerary that retraces a path of exile. To have "been there" (recall the headline) was, in this telling, to have been a tourist.

What were the effects of the press's very selective portraits of the Israeli traveler? They policed the borders around national identity and culture. They regulated and performatively reinstated the portrait of normative Israeliness on which the state had been founded, sustaining the terms of the dominant Israeli discourse in which "Israeli" connoted both (and only) European and Jew. This production of normativity relied on a central dyad: because the scene of first contact was meant to be understood as an interface between nation-states (not merely leisure travelers) after a history of enmity, "discovery" depended on the isomorphism of tourist and citizen - that is, tourist as (always already) representative of his or her nation-state. In the slippage between these terms (tourist and citizen), the Ashkenazi Jew was installed not only as normative Israeli tourist but also as normative Israeli citizen-subject. As I have suggested, normativity was constituted through a logic of difference — not only in the difference between the Israeli tourist and Jordanian host but between Jew and Arab. The aforementioned photograph of first contact provides a graphic illustration of this logic — in the dyadic relationship between the foregrounded Israeli tourist and (presumably) back- 
grounded Bedouin laborer, visible only in profile (fig. 2). The banality of this image, clearly legible as "the tourist snapshot," helps to naturalize the narrative. Handheld camera is to tourist as Ashkenazi Jew is to Israeli. The link between signifier and signified is offered as incontestable-equally recognizable, equally banal. The press's tales of tourism worked to preserve the disappearance of this foundational fiction about Israel and its citizenry - to reproduce and secure it, in the face of its vanishing. ${ }^{16}$

\section{The Tourist as Mimic}

Yet regional travel during the Oslo era was not unidirectional. In the mid-1990s, Arab tourists from neighboring states were beginning to appear in the Israeli metropolis. Jordanians composed the largest tourist population. In 1994, following the Washington Declaration, some 25,000 Jordanians toured the Jewish state, and by 1995, this number had risen to over 80,000 (Israeli Ministry of Tourism 1996: 14; 1998: 19). ${ }^{17}$ As tourist agents in Amman attested, the demand was far greater than the number of visas granted - due to rigid Israeli screening of potential applicants in an effort to sort (the state argued) bona fide travelers from migrant laborers, terrorists, and those seeking permanent residence (Stein 1995). In 1994, as the mainstream Israeli press celebrated the "first time" voyages of Ashkenazi tourists in Jordan, it uneasily anticipated the beginning of this tourist influx ("They Are Coming to See Eilat" [Rubin 1994]). Two years later, headlines predicted that "A Million Arab Tourists Will Visit Jerusalem and Bethlehem" (Kaveh 1996). Small numbers of Muslim Arabs from neighboring countries had visited Israel in the years before the Oslo accords, often illegally or through third-party passports. Yet, with the emergence of a regional "peace," the Israeli state and private sector predicted unprecedented numbers of Arab visitors-a prediction that generated considerable concern.

Not all Arab tourists were regarded equally. ${ }^{18}$ The Israeli press and private

16. As noted above, this fiction was being challenged in unprecedented ways during the 1990s: by the growing parliamentary power and public visibility of SHAS, Israel's Mizrahi party; by the mobilization of Palestinians with Israeli citizenship; by rising numbers of non-Jews in the nation-state (foreign workers and Russian immigrants); and by the looming question of how to retain the Jewishness of the state in the midst of the New Middle East.

17. By law, Palestinian residents of Jordan were permitted entry into Israel and the occupied territories after the 1967 occupation in the framework of family reunification; in practice, the number of visas granted by Israel was limited.

18. The Israeli state's policy on incoming Arab and/or Muslim tourism was contradictory and perpetually shifting. The Israeli Ministry of Tourism (1995: i) declared Israel open to "all Muslim and 
sector eagerly anticipated "the wealthy of Amman" and the Gulf States, "tempted by Eliat's nightclubs and the availability of alcohol," destined for Tel Aviv's malls and tourist complexes (Plotzker 1994; Sugarman 1994). Yet, more often than not, this incoming population was depicted as an underclass mob. In the wake of the Washington Declaration, as rumors circulated about a "major influx of Muslim pilgrims," newspapers assured their readers that "black clad women from Iran are not [yet] thronging the streets of Tel Aviv" (Shapiro 1995b). In an image drawn from the orientalist archive, the "throng" threatened in both its magnitude and its illegibility.

In the winter of 1995, the Israeli press began to describe illegitimate Arab tourists with unrecognizable itineraries. Of particular concern was the growing population of Jordanians seeking tourist visas for travel in Israel. Popular newspapers began to investigate cases of Jordanians who "came to visit — and stayed" in violation of their visas. Articles documented scores of Jordanian men working in construction and Jordanian women selling sex in northern Israeli towns (Cohen 1995b; Sadeh 1995). One headline warned: “Arab Towns [in Israel] Being Used as Hiding Places for Illegal Tourists" (Dar 1996). Newspapers exposed such crimes and encouraged readers to participate in the regulatory work of the state.

Indeed, many "tourists" were working in Israel during this period in violation of their visas. They infiltrated with relative ease, thanks to the growing number of foreign workers imported by the Labor Ministry to replace the blue-collar Palestinian workforce, deemed a political risk (Ja'afari 1996). ${ }^{19}$ By 1995, some 89,000 foreign laborers worked legally in Israel (from Ghana, Romania, Thailand, and the Philippines) and some 100,000 more worked illegally on tourist visas (Foreign workers 1997). For the state, foreign labor promised clarity. Unlike the Palestinian workforce they had replaced, these laborers were obligated to leave after the expiration of their work visas. But perhaps more critically, they bore a marked difference from both Jews (qua good citizens) and Arabs (qua prototerrorists) - an ethnoracial difference inscribed on their bodies, thereby easing the labor of policing their movements. Amid growing Israeli concern for their rising numbers, foreign workers began to appear in the Hebrew press in spring 1996. True to their visas, many spoke in tourist idioms: "I'm meet-

Arab travelers"; two months later, ministry spokespersons "clarified" that Muslim tourism to Jerusalem would not be "encouraged" at a time when the political status of the city was so fiercely contested (Hareuveni 1995).

19. Because of their ability to "pass," some Jordanian travelers were victims of police violence intended for Palestinians from the occupied territories (Cohen 1995a). 
ing a lot of girls. It's interesting for me here, because it's another country" (Sapir 1996).

Jordanians also populated the illegal workforce during this period. ${ }^{20}$ Yet unlike the foreign worker on tourist visa, who blended easily in the laboring crowd, the fraudulent Jordanian worker-tourist could be easily recognized — or so the press assured its readers. At issue was a failure of resemblance: they simply didn't look like tourists in any normative sense. One prominent daily newspaper described a typical scene at the Israeli/Jordanian border. Many alleged tour groups crossed the border together, the article reported, only to disband on the other side: "Immediately after the border crossing, they separate and each one travels to a different place. There are some who come with mattresses and equipment, and it's clear that they aren't exactly tourists that are coming to tour and then return to Jordan" (Sadeh 1995).

A crime is being documented here, that of Jordanians who try to pass as tourists. Their fraudulence is transparent ("it's clear that they aren't exactly tourists"). Criminality is deduced from the truth of the visible-from material artifacts that do not bear the standard markers of leisure travel. In the place of a handheld camera, we see mattresses and kitchen implements, objects connoting homecoming, not tourism.

This tale of tourism and criminality forestalled a much more threatening narrative about the New Middle East. Like accounts of Palestinian travel to Jordan, in which familial visits were recast as leisure itineraries, this story of tourism/ criminality displaced the legacy of exile and diaspora. Contrary to the discourse of the press, these visitors had little need to "hide," and this was precisely their threat. Most Jordanians on tourist visa were of Palestinian origin. Thus their ability to pass as laborers, or as citizens of Israel, rested in a history of familial and/or ethnonational ties to the Palestinian communities and populations in which they sought refuge. They had little need for concealment. Their bodies could look "at home" in Israel in ways that the state could not easily control.

On what, then, did criminality depend? The fraudulence of the Jordanian visitor rested not merely in the failure of resemblance, but also in the threat of likeness. Unlike the case of Israeli tourism in the Arab world, where tourist and citizen were offered as isomorphic terms, the authenticity of the Arab tourist rested precisely in her or his visible difference from the Israeli citizen. Indeed, suspicion

20. Unlike other foreign workers, Jordanian laborers were not provided with housing, which radically cut corporate costs for Israeli companies. Salaries in Israel were often three times that available for comparable labor in Jordan and Egypt (Ja'afari 1996). 
arose at precisely the moment when visitors began to look "at home." Their menace cohered at this place of liminality where lines could not be drawn clearly. Anxiety came to the fore at the moment of mimicry, when the alleged tourist began to resemble the citizen. The press intervened to regulate the difference.

Yet whom did the Arab travelers resemble? First and foremost, they bore an ethnonational resemblance to Palestinian laborers from the occupied territories and Palestinian citizens of the state, thus enabling their successful concealment in Israeli towns and work sites. But their likeness, and its menace, was broader still. In the mid-1990s, these visitors raised the specter of an unpleasant past, one the state had long ignored. Images of laden travelers recalled the mass flight of Palestinians after the founding of Israel - travelers similarly burdened with mattresses and kitchen implements, fleeing with their homes on their backs. But the figure of the Arab traveler also signaled a future that Jewish Israel imagined with considerable trepidation. These figures seemed to foretell the mass return of Palestinian refugees to their homes inside Israel. ${ }^{21}$ As documented in the Israeli press, many Jewish Israelis feared that the peace process would make this return possible: "We are going to gain in this 'peace,' but maybe, at the same time, lose everything: our country, our Jewish identity, and, in the end, the opportunity to live in what we once called the land of Israel. . . They expect millions of tourists [here] from the whole world. The foreigners will fill the streets of our cities in masses, until it is no longer clear who lives here and who is a tourist" (Rozen 1994). What exactly is tourism's menace in the age of the Oslo peace process and the globalization of Israeli economy and culture? As this passage from the Israeli press suggests - in words spoken by a prominent Jewish environmentalist - its menace lay in mimicry. In the midst of an urban crowd, at the heart of the Jewish Israeli metropolis, the line between tourist and citizen might blur. Persons from outside the nation-state might suddenly make themselves at home, protected by the cloak of resemblance. In the urban crowd, as foreigners mingle with citizens, as visitors walk the streets of Israel, making themselves at home in the nationstate, these tourists/mimics unsettle dominant Israeli geographies, notions of national identity, accounts of its history. These spectral figures threaten to render "home" itself unrecognizable.

21. In the 1990s, this nightmare was beginning to materialize, as Palestinians with deeds to property inside Israel (particularly West Jerusalem) began to explore legal restitution (Cohen 1996). 
Much scholarship of the last decade has encouraged us to think "beyond the nation"- to consider the unbundling of nation-states in the age of global capitalism (Appadurai 1996; Basch, Schiller, and Szanton Blanc 1994; Cheah and Robbins 1998). Discussion of borders tends to focus on their new degrees of permeability. Traveling subjects, traversing state lines, have been privileged illustrations of global processes. As Katherine Verdery (1994) has noted, the prefix trans- in transnationalism seems to connote both border crossing and transcendence - the transcendence of "the national" form. Yet the case of mid-1990s Israel requires a different account. The diplomatic and economic reconfiguration of the region in the peace process era, with its cross-border flows and circuits, necessitated the fortification of the nation-state and the remaking and remapping of Israel's territorial and symbolic contours. Rather than tell a story of (Israeli) denationalization and/or deterritorialization in the global era, as Saskia Sassen (1998, 2000) and Arjun Appadurai (1996) have, my analysis illustrates processes of both renationalization and reterritorialization in the midst of globalizing processes. $^{22}$ Flows across state lines produced the need to defend and remake Israel's spatial and ideological divides, to shore up the borders around normative Jewish Israeli identity, culture, and territory.

The mid-1990s was a period of tremendous social and political change within Israel and on its borders. While politicians and businesspeople could predict the future economic landscape of Israel and the Middle East (or so many of them thought), the sociopolitical effects of regional realignment remained uncharted, and threateningly so. For even as "peace" promised to globalize Israel, it also threatened to Arabize it, hence the fear of a tourist mob. The press's stories of "first contact" respond to this anxiety by shoring up the borders of the nationstate, demarcating clear parameters around Israeli identity and the subjects that could claim it, preserving "Israeliness" as both a Jewish and European domain in the face of shifting geopolitics and newly flexible borders. Of course, Israel was always already Arabized, and this was precisely the issue, the locus of fear and anxiety. The possibility of resemblance-of Arab tourist to citizen — threatened the fiction of Ashkenazi normativity by making visible the history of Palestinian dispossession and Mizrahi disfranchisement on which this fiction depended.

Yet the anxiety that attends the tourist mob also suggests that the past and present geography of Israel and the Middle East was/is not under control in any

22. I am drawing on James Ferguson and Akhil Gupta's (1992) account of reterritorialization. 
strict sense. While the Israeli state could prevent the emergence of a sovereign Palestinian state (as it continues to do), it could not control the changing demographics within the region and nation-state and the promise of a Palestinian majority within the area of Israel/Palestine within the next half century. While the Israeli state could/can regulate the movement of bodies on its borders through militarized checkpoints and visa restrictions, it could not (and cannot) determine the multiple effects produced by the continued globalization of Israeli economies, cultures, and knowledges. The haunting images within the Israeli press - of Palestinian Arabs in tourist guise, returning to claim their homeland - might yet foretell an alternative Israeli future.

Rebecca L. Stein is an assistant professor of anthropology at the University of Minnesota. Her work on Israeli political culture has appeared in Social Text and Middle East Report. She is the author of National Itineraries: Tourism, NationMaking, and Geographies of "Peace" in Contemporary Israel (forthcoming).

\section{References}

Abu-Tuma, Khalid. 1995. 'Iton beyarden: Hatayarim hayisraelim qamtzamim veokhlim raq falafel [Newspaper in Jordan: The Israeli tourists are stingy and only eat falafel]. Yerushalayim, 8 September.

Appadurai, Arjun. 1996. Modernity at large: Cultural dimensions of globalization. Minneapolis: University of Minnesota Press.

Aruri, Naseer H. 1995. The obstruction of peace: The United States, Israel, and the Palestinians. Monroe, Maine: Common Courage.

Avraham, Eli. 1993. Hatiqshoret beyisrael: Siquran shel 'ayarot hapituah [The media in Israel: Coverage of the development towns]. Tel Aviv: Breirot.

Bar-Siman-Tov, Yaacov. 1994. Israel and the peace process, 1977-1982: In search of legitimacy for peace. Albany: State University of New York Press.

Basch, Linda, Nina Glick Schiller, and Cristina Szanton Blanc. 1994. Nations unbound: Transnational projects, postcolonial predicaments, and deterritorialized nation-states. Langhorne, Pa.: Gordon and Breach.

Beinin, Joel. 1998. Palestine and Israel: Perils of a neoliberal, repressive pax Americana. Social Justice 25, no. 4: 20-39.

Ben Ari, Mordecai. 1996. Peace tourism update. Jerusalem: Israeli Ministry of Tourism.

Ben Efrat, Yacov. 1993. Close minded: Changing the nature of control. Challenge, May-June, 6-7. 
Blackburn, Nicky. 1995. Reaching the threshold. Link: Israel's International Business Magazine, fall, 21.

Burckhardt, John Lewis. 1829. Travels in Arabia: Comprehending an account of those territories in Hedjaz which the Mohammedans regard as sacred. London: Henry Colburn.

Cheah, Pheng, and Bruce Robbins, eds. 1998. Cosmopolitics: Thinking and feeling beyond the nation. Minneapolis: University of Minnesota Press.

Chetrit, Sami Shalom. 2000. Mizrahi politics in Israel: Between integration and alternative. Journal of Palestine Studies 29, no. 4: 51-65.

Clawson, Patrick. 1994. Tourism cooperation in the Levant. Policy Focus Series, no. 26. Washington, D.C.: Washington Institute for Near East Policy.

Clifford, James. 1989. Notes on theory and travel. Inscriptions 5: 177-87. 1992. Traveling cultures. In Cultural studies, edited by Lawrence Grossberg, Cary Nelson, and Paula A. Treichler. New York: Routledge.

Cohen, Hillel. 1995a. Shalom 1: Tayar Yardeni mitlonen 'al alimut shotrim yisraelim [Peace 1: Jordanian tourist complains about violence from Israeli police]. Kol Ha ir 27 October.

- 1995b. Shalom 2: Palestinim ezrahei yarden baim ketayarim venisharim beyisrael [Peace 2: Palestinian citizens of Jordan come as tourists and stay in Israel]. Kol Ha ir, 27 October.

—. 1996. Hehanu et hacheck [We prepared the check]. Kol Ha ir, 16 February.

Cohen, Yossi. 1994. 20 dinar lezug, kolel mizug avir [Twenty dinars per couple, including air conditioning]. Kol Ha' ir, 22 July, sec. 1, p. 65.

Courbage, Youseff. 1999. Reshuffling the demographic cards in Israel/Palestine. Journal of Palestine Studies 28: 21-39.

Dar, Yuli. 1996. Yishuvei ha'aravim meshamshim mekom mistor letayarim bilti huquiim [Arab towns used as a hiding place for illegal tourists]. Kol Hatzafon, 26 January.

Farsakh, Leila. 2000. Under siege: Closure, separation, and the Palestinian economy. Middle East Report, 30, no. 4: 22-24.

Government of Israel. 1996. Development options for cooperation: The Middle East/East Mediterranean region. Jerusalem: Government Publishing House.

Greenblatt, Stephen. 1991. Marvelous possessions: The wonder of the new world. Chicago: University of Chicago Press.

Ferguson, James, and Akhil Gupta. 1992. Beyond "culture": Space, identity, and the politics of difference. Cultural Anthropology 7: 6-24.

Foreign workers in Israel. 1997. Migration News 4, no. 8. 
Hareuveni, Eyal. 1995. Hasar Bar'am neged tayarut muslemit [Minister Baram is against Muslim tourists]. Kol Hair, 1 September.

Hazbun, Waleed. 2002. Mapping the landscape of the "New Middle East": The politics of tourism development and the peace process in Jordan. In Jordan in Transition, edited by George Joffé. New York: Palgrave.

Hiel, Betsy. 1995. Tourism revival in the land of the pharaohs. Arab DataNet (Web publication at www.arabdatanet.com), 2 June.

hooks, bell. 1992. Representing whiteness in the black imagination. In Cultural studies, edited by Lawrence Grossberg, Cary Nelson, and Paula Treicher. New York: Routledge.

Israeli Ministry of Tourism. 1995. Regional tourism cooperation development options. Jerusalem: Government Publishing House. 1996. Tourism to Israel, 1995: Statistical report. Jerusalem: Government Publishing House.

- 1998. Tourism to Israel, 1997: Statistical report. Jerusalem: Government Publishing House.

Iss, Edna. 1995. Sha'ah vahetzi miteveriah [An hour and a half from Tiberias]. Yedi'ot Aharonot, 18 December.

Ja'afari, Kamal. 1996. Foreign Arab workers in Israel. Challenge, JanuaryFebruary, 14-15.

Kaplan, Caren. 1996. Questions of travel: Postmodern discourses of displacement. Durham, N.C.: Duke University Press.

Kaspit, Ben. 1996. Haqatari: Yedidenu hehadash mimizrah [The Qatari: Our new friend from the east]. Ma'ariv, 5 April, 27.

Kaveh, Avshalom. 1996. Milyon tayarim 'araviim yevaqru biyerushalayim uveveit-lehem 'im heskem Oslo bet [A million Arab tourists will visit Jerusalem and Bethlehem with the realization of Oslo II]. Davar Rishon, 23 January.

Klein, Chaim H., ed. 1973. The second million: Israel tourist industry, past, present, and future. Jerusalem: Amir.

Lavi, Aviv. 1995. Natbag 2000 [Airport 2000]. Kol Ha ir, 29 December.

Lavi, Moshiq. 1995. Shloshim devarim shelo yad'atem 'al suriah [Thirty things you didn't know about Syria]. Yedi ot Aharonot, 1 December.

Lavie, Smadar. 1988. Sinai for the coffee table: Birds, Bedouins, and desert wanderlust. Middle East Report 18, no. 1: 40-44.

1990. The poetics of military occupation: Mzeina allegories of Bedouin identity under Israeli and Egyptian rule. Berkeley: University of California Press. 
Levinshtein, Revital. 1996. Masof 'aravah niftah lema'avar klei rekhev pratiim [Arava border crossing opens to private vehicles]. Ha'aretz, 8 April, sec. 1.

Levy, André. 1997. To Morocco and back: Tourism and pilgrimage among Moroccan-born Israelis. In Grasping land: Space and place in contemporary Israeli discourse and experience, edited by Eyal Ben-Ari and Yoram Bilu. Albany: State University of New York.

Lior, Gad. 1994. Hig'ati lasel'a haadom [I got to the red rock]. Yedi'ot Aharonot, 18 July, sec. 1, p. 10.

Malkki, Liisa. 1995. Refugees and exile: From "refugee studies" to the national order of things. Annual Review of Anthropology 24: 495-523.

Ministry of Finance, Government of Israel. 1994. Focus on the economy: Possible economic implications of the peace treaty. Jerusalem: Government Publishing House.

Mundlak, Guy. 1998. Labor in a peaceful Middle East: Regional prosperity or social dumping? In The Middle East peace process: Interdisciplinary perspectives, edited by Ilan Peleg. Albany: State University of New York.

Murphy, Emma. 1995. Stacking the deck: The economics of the Israeli-PLO accords. Middle East Report 25, no. 3/4: 35-38.

Plotzker, Savar. 1994. Hahalom evar kan [The dream is already here]. Yedi ot Aharonot, 25 July.

Pratt, Mary Louise. 1992. Imperial eyes: Travel writing and transculturation. London: Routledge.

Quandt, William B. 1993. Peace process: American diplomacy and the ArabIsraeli process since 1967. Berkeley: University of California Press.

Rabbani, Mouin. 1996. Palestinian authority, Israeli rule: From transition to permanent arrangement. Middle East Report 26, no. 4: 2-6.

Rozen, Rami. 1994. Hashalom hashahor hazeh [This black peace]. Ha'aretz Supplement, 9 September, 50.

Rubin, Betsalel. 1994. Hem baim lirot et Eilat [They are coming to see Eilat]. 'Erev'Erev, 26 December.

Sadeh, Dani. 1995. 6,000 yardenim bau leviqur venisharu bashetahim [6,000 Jordanians came to visit and stayed in the territories]. Yedi'ot Aharonot, 3 September.

Sapir, Shuli. 1996. 'Arbev et hatiah, Jonny [Mix the plaster, Jonny]. Davar Rishon, 26 March.

Sassen, Saskia. 1998. Globalization and its discontents: Essays on the new mobility of people and money. New York: New Press. 
2000. Spatialities and temporalities of the global: Elements for a theorization. Public Culture 12: 215-32.

Schrag, Carl, and Steve Rodan. 1994. Closer than you think. Jerusalem Post Magazine, 29 July, 11.

Sedan, Gil. 1999. Moroccan Jews mourn death of king. Jewish News of Greater Phoenix (available on-line at www.jewishaz.com/index.shtml), 30 July.

Seliktar, Ofira. 1998. The peace dividend: The economy of Israel and the peace process. In The Middle East peace process: Interdisciplinary perspectives, edited by Ilan Peleg. Albany: State University of New York Press.

Shafir, Gershon, and Yoav Peled. 2000. Peace and profits: The globalization of Israeli business and the peace process. In The new Israel: Peacemaking and liberalization, edited by Shafir and Peled. Boulder, Colo.: Westview.

Shahak, Israel. 1994. Israeli trade with Arab countries: Vegetables and drugs. Shahak Report, no. 144 (26 August).

Shalit, David. 1994. Haya'ad haba: Dameseq [The next destination: Damascus]. Ha'aretz Supplement, 25 November, 33-35.

Shapiro, Haim. 1995a. Israelis flock to Jersash festival. Jerusalem Post, 12 July, 3. 1995b. Across the great divide. Jerusalem Post Magazine, 13 October, 20.

Shehori, Alon. 1996. Kamah medinot 'araviyot yiftehu bashevu'ot haqerovim netzigut tayarutit betel-aviv [Several Arab countries will open tourist offices in Tel Aviv in upcoming weeks]. Israel Tourist Guide, 1 February, 1.

Stein, Rebecca Luna. 1995. Itineraries of peace: Remapping Israeli and Palestinian tourism. Middle East Report 25, no. 5: 16-19.

1998. National itineraries, itinerant nations: Israeli tourism and Palestinian cultural production. Social Text 56: 91-124.

Sugarman, Margo Lipschitz. 1994. Make tours, not war. Jerusalem Report, 25 August, 34-36.

- 1996. Tourists with reservations. Jerusalem Report, 31 October, 47-48.

Teiman: Mathilah lehitpateah la'olam [Yemen: Starting to open to the world]. 1996. Ma'ariv, 5 April, Tayarut section, 26.

Tunisia: Neot midbar basaharah [Tunisia: Oasis in the Sahara]. 1996. Ma'ariv, 5 April, Tayarut section, 27.

Verdery, Katherine. 1994. Beyond the nation in Eastern Europe. Social Text 38: $1-19$.

Ya'ari, Ehud. 1995. The Jordanian option. Jerusalem Report, 9 February, 28-30.

Zilberfarb, Ben-Zion. 1994. The effects of the peace process on the Israeli economy. Israel Affairs 1 (autumn): 84-95. 